\section{A LOGGERHEAD SHRIKE ENCOUNTER}

Often the most thrilling experiences in the field are also the most unexpected. This proved to be the case for me on 8 May 1993 as I conducted grassland bird surveys as part of my Ph.D. research. I was working in the Matador Community Pasture $(30 \mathrm{~km}$ southeast of Kyle, $\mathrm{SK}$ ) and had done two surveys that morning, which had dawned cool and bright. To ward off the earlymorning chill and heavy dew, I was decked out in warm clothes, rubber boots and rain pants. The sun was finally starting to gain strength as I finished my last sampling period, so I decided to lie down and relax for a few minutes.

I had just closed my eyes and was enjoying the warm sun on my face when the sound of nearby, rapid wingbeats and a slight pinch jolted me awake. A Loggerhead Shrike had landed on my left knee! There was no doubt as to the bird's identity. At such close quarters its distinctive black facial mask and dark bill were unmistakable. As I looked up with a start, the bird leapt away and flew off over a slight rise. I'm not sure which of us was more surprised!

Why had it ventured so close? Shrikes, hawks and other predatory birds are often observed on elevated perches, from fence lines to hydro poles, where their keen eyesight can be used to full advantage in the search for prey. Perhaps my upraised knee was simply a convenient perch in an otherwise flat prairie landscape. Another more outlandish possibility is that it mistook me for food. After hearing this story, friends joked about finding me impaled on a hawthorn bush or barbed wire, which

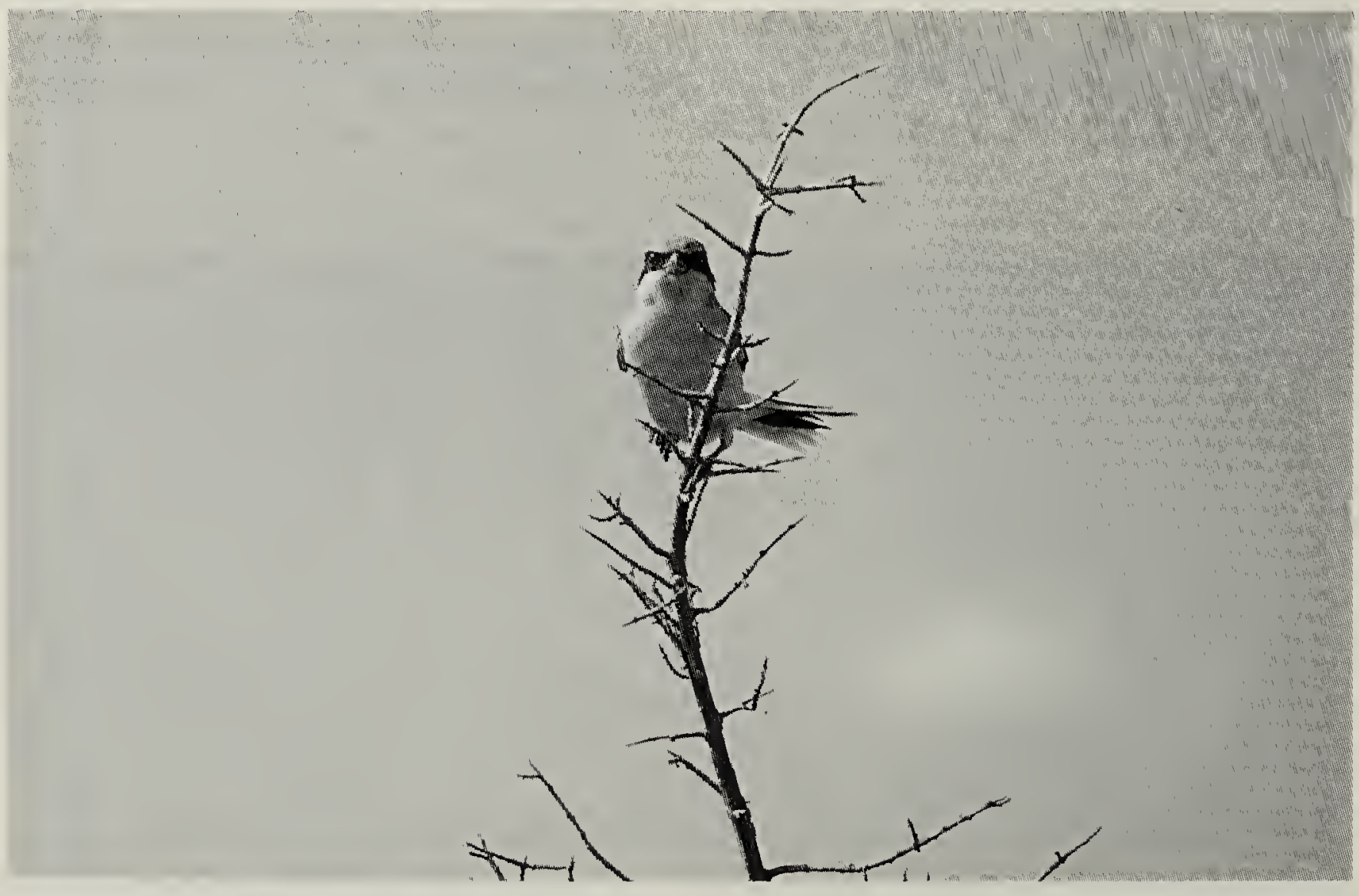




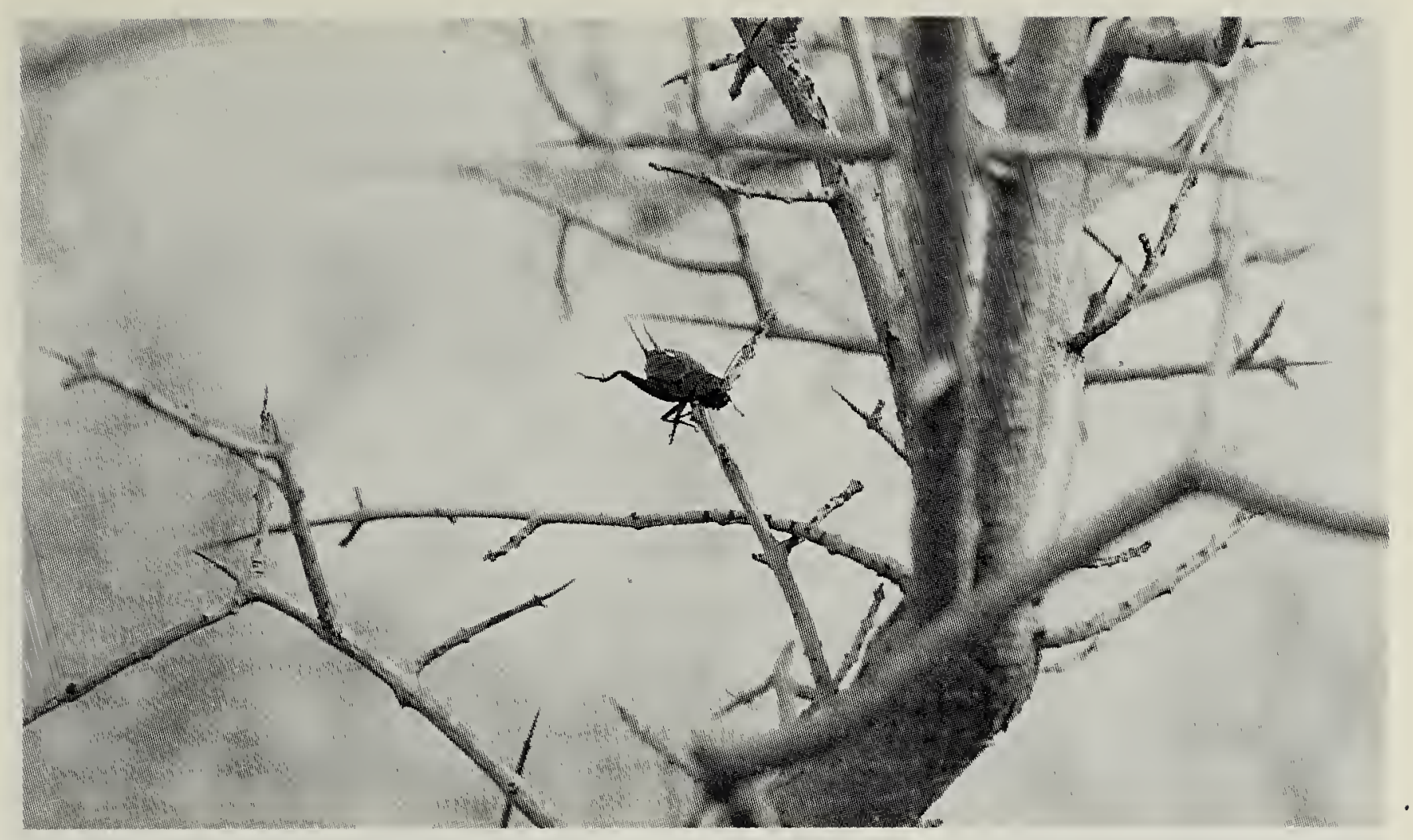

Cricket impaled by Loggerhead Shrike

Doug Collister

is how shrikes sometimes deal with their prey.

Whatever the reason, I feel fortunate to have had this experience. Loggerhead Shrikes are threatened in Western Canada and endangered in the east. ${ }^{2}$ Habitat loss is thought to be part of the problem, especially large-scale conversions of pasture to cropland. 2,3 Matador is particularly valuable in this light since much of the pasture (including the spot I was lying on) is a rare and significant type of mixed-grass prairie which has never been cultivated. As shrike habitat and for many other reasons we should continue to protect and study it.

1. EHRLICH, P.R., D.S. DOBKIN and D. WHEYE. 1988. The birder's handbook: a field guide to the natural history of North American birds. Simon \& Schuster Inc., New York, NY. 785 pp.

2. JOHNS, B., M. CADMAN, D. BIRD, R. BJORGE, K. DE SMET, W. HARRIS, D. HJERTAAS, P. LAPORTE and R. PITTIWAY. 1994. National recovery plan for the Loggerhead Shrike. Recovery of Nationally Endangered Wildlife Committee Report No. 7. Ottawa. $32 \mathrm{pp}$.
3. TELFER, E.S. 1992. Habitat change as a factor in the decline of the western Canadian Loggerhead Shrike, Lanius ludovicianus, population. Can. Field-Nat. 106:321-326.

- Glenn C. Sutter, Dept. of Biology, University of Regina, Regina, SK. S4S 0A2.

\section{GOPHER VS CHIPMUNK - AND THE WINNER IS! THE GREAT PEANUT CAPER}

First, a little background to my story. As I live in Regina, I really enjoy visiting a friend who lives on a farm east of Southey. On several previous occasions, I had fed shelled peanuts to a "Least" chipmunk that showed up one day by the house. The chipmunk would come up to my hand and take an unshelled peanut from my fingers. I observed him eating it. He would slowly unshell it, carefully take the husk from it and eat it with great refinement.

After a couple of weeks of throwing peanuts to this chipmunk, I began to notice that a "Thirteen-striped" gopher (yes, I counted his stripes) was observing (from a distance) 